\title{
MANAGEMENT OF MEDICAL WASTE IN DEVELOPING COUNTRIES: A SYSTEMATIC REVIEW
}

\author{
Asriyanti Bandaso, Dumilah Ayuningtyas
}

Masters Program in Public Health, Universitas Indonesia

\begin{abstract}
Background: Health care activities can generate different kinds of hazardous waste. Management of hospital health care waste (HCW) especially in developing countries is still a big challenge. Medical waste can result in environmental and occupational health risk. This study aimed to review systematically the management of medical waste in developing countries.

Subjects and Method: This was a systematic review conducted according to the PRISMA model. This review was conducted by searching published articles from 2014 to 2019 from databases including Proquest and Scopus. The inclusion criteria were English dan open access.

Results: Hospital medical waste management in developing countries was poor. It increased the risk of spreading infections such as HCV, HBV, and HIV. Poor management of hospital medical waste was affected by lack of an effective waste management plan, lack of resources, lack of budget, lack of facilities, and poor hospital staff awareness. Budget, facility, staff, surveillance, and audits were essential to ensure safe and appropriate hospital waste management practices.

Conclusion: Poor management of hospital medical waste is affected by lack of an effective waste management plan, lack of resources, lack of budget, lack of facilities, and poor hospital staff awareness.
\end{abstract}

Keywords: hospital, medical waste, management, developing country.

\section{Correspondence:}

Asriyanti Bandaso. Masters Program in Public Health, Universitas Indonesia, Depok, West Java. Email: bandaso.asri@gmail.com. Mobile: 08129583283.

\section{BACKGROUND}

The high amount of waste and environmental pollution has been a major concern over the past few decades. Appropriate waste management practice is essential for the safety and well-being of all hospital staff, patients and also for a safe, healthy environment. Health Care Waste management system requires proper planning, the implementation of hazardous Health Care Waste management plan, as well as monitoring of waste management practice.

Every health facility must have a waste management policy and a waste management plan. Through policy and plan, standard operating procedures can be established. They can determine operating procedures, training, roles, and responsibilities for employees in carrying out diffe- rent waste management tasks.

Therefore, there are many authorities concerned with health issues. They have given significant attention to waste management practices. However, hospital or Health Care Waste management is a big challenge in developing countries. It can be overcome by following certain basic steps for waste management, such as identifying, evaluating, treating, transporting and disposing the hospital waste.

Establishing rules and regulations, selecting special staff, educating non-special staff regarding waste management, monitoring and auditing are essential to ensure safe practices for hospital waste disposal. There will be a positive effect on the environment and population if waste management practice is carried out

The $6^{\text {th }}$ International Conference on Public Health Best Western Premier Hotel, Solo, Indonesia, October 23-24, 2019 | 7 https://doi.org/10.26911/the6thicph-FP.01.02 
appropriately (Baluch and Khan, 2017).

The World Health Organization (WHO) handbook, known as the "Blue Book" is a safe, sustainable and affordable handbook on health care waste management. Health care waste generated from medical facilities is a combination of hazardous and non-hazardous materials. The hazardous component of hospital waste is infectious waste. It is around one third of the total waste produced by health facilities. Poor hospital waste management is associated with an increased risk of spreading deadly infections such as $\mathrm{HCV}, \mathrm{HBV}$ and HIV (Blenkharn. 2014).

The concern arises when systematic waste management is not carried out. Systematic waste disposal helps to overcome health problems, environmental factors, resources, and economic problems. The waste produced is a great concern to the population including individuals, communities, local authorities, non-governmental authorities and governmental authorities. The main reasons for improper methods of managing hospital waste in developing countries are lack of resources and lack of awareness. In recent years, government officials, stakeholders, communities and nongovernmental organizations, have become part of a chain of systematic activities involved in the effective waste disposal (Baluch and Khan, 2017).

This review aimed to observe waste management practices (collection of hospital waste, segregation, storage, collection, transportation, waste management, disposal inside and outside the hospital).

\footnotetext{
SUBJECTS AND METHOD

1. Design of the Study

This study was a systematic review through a review of articles on hospital waste mana-
}

gement practices in developing countries using the PRISMA (Preferred Reporting Items for Systematic Reviews and Metaanalysis) approach.

\section{Inclusion and Exclusion Criteria}

The inclusion criteria of the articles were hospital medical waste management practices in developing countries, studies that described how hospital waste management processes were in developing countries. The exclusion criteria were systematic review method. The search for the articles was limited to only English language articles that were accessed from internet searches from databases namely ProQuest and Scopus. The keywords were medical waste AND management AND hospital AND developing countries. The articles that met the criteria were collected and systematically checked. In addition, the articles were published from 2014 to 2019 with open access journals. The process of searching and selecting is explained in Figure 1.

\section{RESULTS}

Categorizing data was important, they were categorized by analyzing data based on title, author's name, journal, method and results. The results of data extraction can be seen in table 1. 


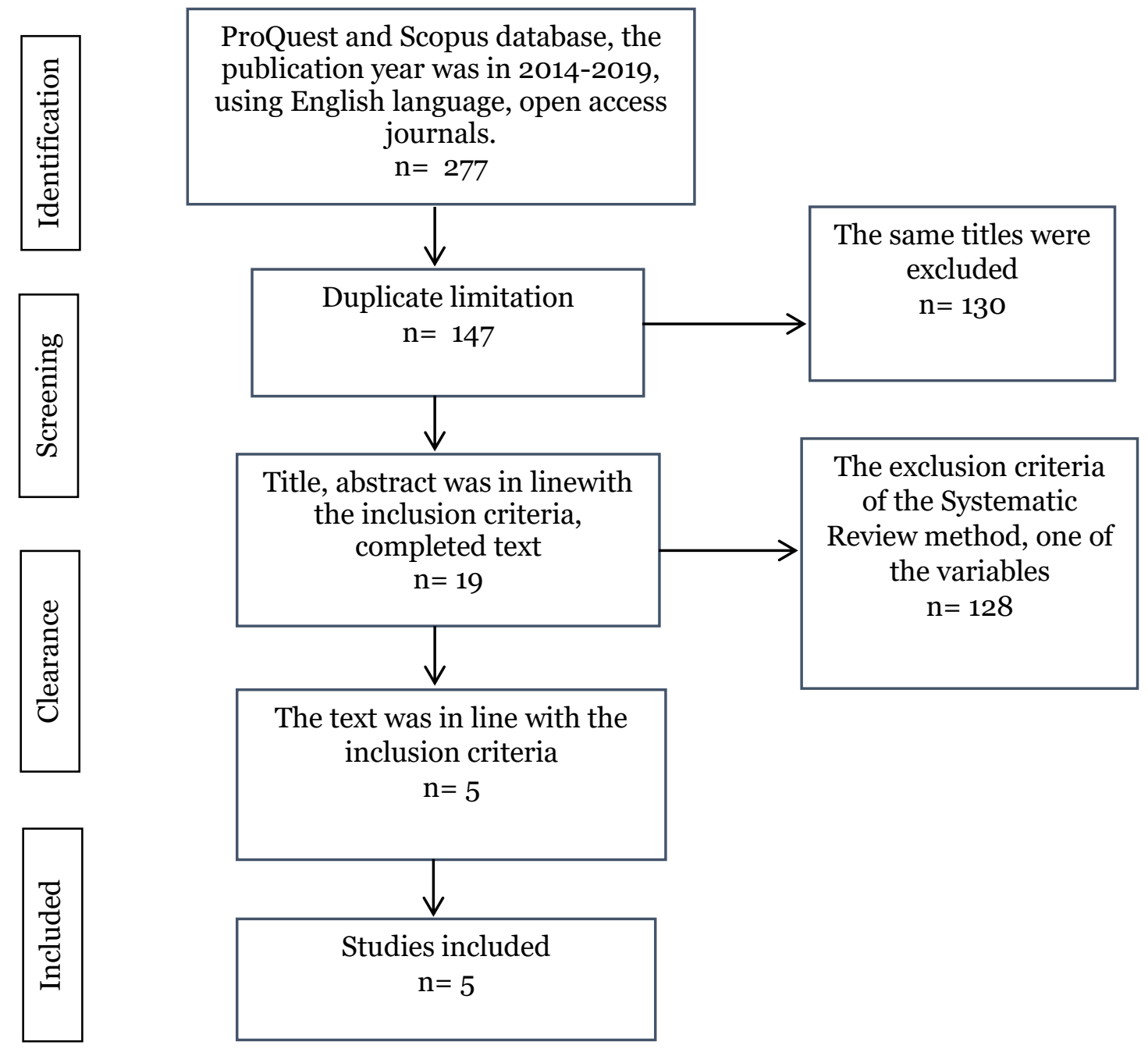

Figure 1. PRISMA flow diagram

Table 1. The Result of the Extraction Data

\begin{tabular}{|c|c|c|c|c|c|}
\hline No & Title & $\begin{array}{l}\text { Author } \\
\text { (Year) }\end{array}$ & Journal & Method & Result \\
\hline 1. & $\begin{array}{l}\text { Evaluation of } \\
\text { Waste Mana- } \\
\text { gement Prac- } \\
\text { tices in One of } \\
\text { the Leading } \\
\text { Public Sector } \\
\text { Hospitals at } \\
\text { Karachi }\end{array}$ & $\begin{array}{c}\text { Baluch et al. } \\
\text { (2017) }\end{array}$ & Gmjacs & Quantitative & $\begin{array}{l}\text { - Handling of medical waste } \\
\text { without the implementation } \\
\text { of international standards } \\
\text { - Poor waste separation and } \\
\text { improper sealing of waste } \\
\text { container } \\
\text { - Did not use protective } \\
\text { equipment } \\
\text { - Lack of training for workers } \\
\text { and non-routine health }\end{array}$ \\
\hline
\end{tabular}

The $6^{\text {th }}$ International Conference on Public Health Best Western Premier Hotel, Solo, Indonesia, October 23-24, 2019|9 https://doi.org/10.26911/the6thicph-FP.01.02 


\begin{tabular}{|c|c|c|c|c|c|}
\hline 2. & $\begin{array}{l}\text { Healthcare } \\
\text { Waste Mana- } \\
\text { gement: an } \\
\text { interpretive } \\
\text { structural } \\
\text { modeling } \\
\text { approach }\end{array}$ & $\begin{array}{l}\text { Thakur et al. } \\
\text { (2016) }\end{array}$ & $\begin{array}{l}\text { Internationa } \\
\text { 1 Journal of } \\
\text { Health Care } \\
\text { Quality } \\
\text { Assurance }\end{array}$ & $\begin{array}{l}\text { Interpretive } \\
\text { Structural } \\
\text { Modelling } \\
\text { (ISM) }\end{array}$ & $\begin{array}{l}\text { checks } \\
\text { - Lack of supervision over } \\
\text { medical waste management } \\
\text { practices } \\
\text { - Demotivation was a major } \\
\text { barrier to waste manage- } \\
\text { ment practices } \\
\text { - Poor managerial commit- } \\
\text { ment and lack of attention } \\
\text { by hospital administrator } \\
\text { - Poor infrastructure, segrega- } \\
\text { tion, and waste transporta- } \\
\text { tion were the main challe- } \\
\text { nges } \\
\text { - Limited budget, resources, } \\
\text { and obsolete facilities } \\
\text { - Lack of training for hospital } \\
\text { workers and awareness of } \\
\text { the dangers of medical waste } \\
\text { - Lack of monitoring and eva- } \\
\text { luation of the waste manage- } \\
\text { ment process }\end{array}$ \\
\hline 3. & $\begin{array}{l}\text { An Analysis of } \\
\text { Medical Waste } \\
\text { Management } \\
\text { Practises in } \\
\text { the Health } \\
\text { Care in } \\
\text { Colombo }\end{array}$ & $\begin{array}{c}\text { Gunawarda- } \\
\text { na (2018) }\end{array}$ & $\begin{array}{l}\text { Manage- } \\
\text { ment of } \\
\text { Environmen } \\
\text { tal Quality: } \\
\text { An Interna- } \\
\text { tional Jour- } \\
\text { nal }\end{array}$ & $\begin{array}{l}\text { Survey } \\
\text { questionnair } \\
\text { e }\end{array}$ & $\begin{array}{l}\text { - Lack of knowledge and } \\
\text { awareness of health staff. } \\
\text { They were crucial for good } \\
\text { waste management } \\
\text { - Limited availability of facili- } \\
\text { ties, funds, resources, and a } \\
\text { lack of managerial responsi- } \\
\text { bility in waste management } \\
\text { - Inadequate waste manage- } \\
\text { ment policies, guidelines and } \\
\text { procedures }\end{array}$ \\
\hline 4. & $\begin{array}{l}\text { Assessment of } \\
\text { Healthcare } \\
\text { Waste Mana- } \\
\text { gement Para- } \\
\text { digms and Its } \\
\text { Suitable Treat- } \\
\text { ment Alter- } \\
\text { native: A Case } \\
\text { Study }\end{array}$ & $\begin{array}{c}\text { Hasan MM, } \\
\text { Rahman MH } \\
\quad(2018)\end{array}$ & $\begin{array}{l}\text { Journal of } \\
\text { Environmen } \\
\text { tal and } \\
\text { Public } \\
\text { Health }\end{array}$ & $\begin{array}{c}\text { Cross } \\
\text { Sectional } \\
\text { Study }\end{array}$ & $\begin{array}{l}\text { - Low awareness of staff in } \\
\text { using safety equipment } \\
\text { - Lack of training regarding } \\
\text { medical waste management } \\
\text { - There was no government } \\
\text { regulation/policy regarding } \\
\text { medical waste management } \\
\text { - Lack of trained workforce, } \\
\text { adequate resources, techno- } \\
\text { logy and facilities }\end{array}$ \\
\hline 5. & $\begin{array}{l}\text { Health Care } \\
\text { Waste Mana- } \\
\text { gement: A } \\
\text { Case Study } \\
\text { from Sudan }\end{array}$ & $\begin{array}{l}\text { Hassan et al. } \\
\text { (2018) }\end{array}$ & $\begin{array}{l}\text { Environ- } \\
\text { ments }\end{array}$ & $\begin{array}{l}\text { Content } \\
\text { analysis, } \\
\text { observation } \\
\text { and inter- } \\
\text { view }\end{array}$ & $\begin{array}{l}\text { Lack of awareness of the da- } \\
\text { nger and long-term conse- } \\
\text { quences (hepatitis and HIV) } \\
\text { of staff on poor medical was- } \\
\text { te management practices }\end{array}$ \\
\hline
\end{tabular}

The $6^{\text {th }}$ International Conference on Public Health Best Western Premier Hotel, Solo, Indonesia, October 23-24, $2019 \mid 10$ https://doi.org/10.26911/the6thicph-FP.01.02 
- No policy was enforced

- Lack of resources and budget

- There was no specific department that handled medical waste management

- Lack of waste management experts and training for staff

\section{DISCUSSION}

Health Care Waste management is one of the main issues in the health care environment and government agencies both in terms of costs and environmental effects and the risks which occur due to lack of compliance with applicable laws. There are many reasons that contribute to this problem, including neglect and poor qualifications of personnel responsible for waste separation and disposal in health care structures, lack of strategies and plans for correct and effective Health Care Waste management, neglect and illegal behavior of transportation of Health Care Waste collectors and outsorcing partner companies. In addition, it is important to know the effect of increasing amounts of waste produced in health organizations and the high costs of overcoming it (Gunawardana, 2018). WHO defines Health Care Waste as "waste generated by health activities that can include a variety of materials, such as needles and hypodermic needles, laundry, body parts, diagnostic samples, blood, chemicals, drugs, medical devices, and radioactive materials". To reduce the risk, it is important to consider the methods used to reduce the high level of waste production. Safe and appropriate Health Care Waste management practices have not received much attention in developing countries. Disposal of hazardous Health Care Waste with general waste has been observed. This is a serious concern because the infectious waste can transmit diseases such as Hepatitis B, Hepatitis C or HIV.
It is important to know the type and amount of waste produced and the separation between hazardous and non-hazardous waste in health facilities because it is the first step towards safe disposal. If the health care waste is not separated, sharp objects or other infectious material can appear. It will certainly endanger the health of residents who are in the location of the waste. Careless management and disposal of waste in health care facilities is now widely recognized as a source of unavoidable infection; in addition, it is synonymous with public perceptions of poor health standards. According to Baluch and Khan, 2017, most of the HCFs ignore separationas an important step to reduce infectious waste. Therefore, proper separation is a major challenge in the HCWM system nowayads. Waste management is largely not in line with applicable regulations. In addition, the hospital administrators do not provide training on handling infectious waste to workers (Thakur and Anbanandam, 2016).

All personnel who work in health facilities and near health care waste, especially hazardous waste, are potentially exposed to danger. The instructions of Health Care Waste management must be given to all people who handle hospital waste, including the use of personal protective equipment and avoiding physical contact with hazardous or infectious waste objects (Baluch and Khan, 2017) Knowledge is important to make workers who handle waste aware of the dangers of infectious waste. In addition, training must be given.

The $6^{\text {th }}$ International Conference on Public Health Best Western Premier Hotel, Solo, Indonesia, October 23-24, 2019| 11 https://doi.org/10.26911/the6thicph-FP.01.02 
Therefore, it is necessary to have a training program for managing and awareness of HCW (Heath Care Waste) workers. In developing countries, staff of HCF (Health Care Facilities) usually bury or burn HCW outdoor due to improper waste management infrastructure. Waste management staff are not motivated by effective waste management practices. Workers do not understand that the disease can occur if they do not follow instructions for managing waste properly (Thakur and Anbanandam, 2016). Health Care Waste management is also related to health risks for staff involved in the health care industry. Therefore, the awareness of various aspects of Health Care Waste management must be assessed frequently. In addition, the training program must be conducted for the staff. Knowledge and awareness among health workers including medical staff and paramedics is essential for adequate management of Health Care Waste. Training should focus on presenting waste management plan, risks associated with waste, protective measures, roles and responsibilities of each staff member, and technical instructions regarding the activities carried out by each staff category (Gunawardana, 2018).

Hospital administrators think that their main focus is to provide better health services. Therefore, poor administrator commitment is the biggest HCWM (Health Care Waste Management) threat. It is because HCWM is not considered as one of the important HCF activities. As a result, it is rarely appreciated by hospital administrators. HCWM practitioners emphasize the need to have maintenance engineers in each CBWTF (Clinical Biomedic Waste Treatment Facilities). However, the position is not available in this facility. Therefore, there must be at least one maintenance engineer who can ensure that the machine is functioning properly (Thakur and Anbanandam, 2016). The main responsibility regarding the process of effective Health Care Waste management must be taken by the higher level of management of each responsible organization. Consequently, they must have a positive attitude towards managing their Health Care Waste to avoid dangerous incidence which can be caused by improper waste management systems and to protect their staff from nonconducive work environments. In addition, policies, guidelines, procedures and codes of practice are the important components of every Health Care Waste management system (Gunawardana, 2018).

Financial problem is one of theobstacles in implementing proper waste management procedures. According to the hospital administrator's perception, HCF is evaluated on services provided, not on waste management practices. Therefore, the fund is mainly focused on the main activities. Experts emphasize to minimize the hospital waste because it can help to achieve cost effectiveness and lead to sustainable waste management. Poor managerial commitment is a major barrier to carrying out logistical functions (Thakur and Anbanandam, 2016). Under a decentralized health system, most of the primary health care institutions rely on local governments, which often have less financial and support resources. Meanwhile, the central government sets the overall policy, especially the policy enforcement that mainly depends entirely on local funding. These fund is often insufficient, especially for hospitals that are more remote and rural (Gao et al., 2018).

The technology chosen for the management and disposal of hospital waste must have the least risk to the health of everyone involved in the process, must ensure a healthy environment, must be economical, and easy to implement (Ghasemi and Yusuff, 
2016). Most of the CBWTFs in developing countries only burn waste, which is expensive and not environmentally friendly. Every ton of waste that is burned produces 25$30 \mathrm{~kg}$ of ash, which must be carefully removed. Microwaving and autoclaving are efficient techniques, but these maintenance facilities are outdated. The result of the combustion can pollute the environment. The experts are not ready to replace incineration with microwaving because it requires investment. Therefore, the government must implement policies to remove old technology (Thakur and Anbanandam, 2016).

National laws are the basis for improving HCW practices in any country. Therefore, a national management plan is needed. It allows the HCWM section to be optimized on a national scale. The law must be supplemented with policy documents and technical guidelines developed for the implementation. This legal document must establish regulations regarding management for various categories of waste, separation, collection, storage, handling, disposal, transportation, responsibilities, and training requirements (Hasan and Rahman, 2018).

Monitoring operational process is important because it can provide continuous feedback. It aims to control the process and improve the existing system. Longterm performance monitoring is an intensive resource needed to evaluate nonconventional systems and improve the existing processes. Implementing an appropriate monitoring process in the system requires tracking and recording records, and reporting the waste management process. During the HCF survey, it was found that most of the HCF managers did not save records and had outsourced the waste disposal process to CBWTF which was approved by the government. During the outsourcing of the HCWD process, it is very important to evaluate partners strategically and quantitatively. Due to the poor performance evaluation criteria, the HCF staff chose their outsourcing partners without a quantitative and rational approach. Therefore, HCF managers must choose a waste disposal partner, after evaluating their various performance parameters (Thakur and Anbanandam, 2016).

Waste management is the responsibility of government authorities. Unfortunately, the regulation is inadequate. It includes the types of facilities available to patients in hospitals and the availability of resources. It is important for hospitals to have the resources available to ensure the effective and safe waste management. The key factors for a safe and healthy population and environment are safe disposal and good Health Care Waste management practices (Baluch and Khan, 2017).

\section{REFERENCES}

Baluch S, Khan RA (2017). Evaluation of waste management practices in one of the leading public sector hospitals at Karachi. Gmjacs, 7(2). Retrieved from http://gmjacs.bahria.edu.pk/wp-content/uploads/2018/o1/paper-06.pdf

Blenkharn I (2014). Healthcare waste and sharps management. British Journal of Healthcare Management, 20(9): 424-427. Retrieved from https://doi.org/10.12968/bjhc.2014.20.9.424

Gao Q, Shi Y, Mo D, Nie J, Yang M, Rozelle $S$ et al. (2018). Medical waste management in three areas of rural China. PLoS ONE, 13(7): 1-14. https://doi.org/10.1371/journal.pone.0200889

Ghasemi MK, Yusuff RBM (2016). Advantages and disadvantages of healthcare waste treatment and disposal alternatives: Malaysian scenario. Pol J Environ Stud, 25(1): 17-25. doi: 10.15244/pjoes/59322

The $6^{\text {th }}$ International Conference on Public Health Best Western Premier Hotel, Solo, Indonesia, October 23-24, 2019| 13 https://doi.org/10.26911/the6thicph-FP.01.02 
Gunawardana KD (2018). An analysis of medical waste management practices in the health care sector in Colombo. Management of Environmental Quality: An International Journal, 29(5): 813-825. https://doi.org/10.1108/MEQ-02-2018-0032

Hassan A, Tudor T, Vaccari M (2018) Health care waste management: A case study from Sudan, environments, 5(8): 89. doi: 10.3390/environments5080089

Hasan MM, Rahman MH (2018). Assessment of healthcare waste management paradigms and its suitable treatment alternative: A case study. Jour- nal of Environmental and Public Health, 2018. https://doi.org/10.115$5 / 2018 / 6879751$

Thakur V, Anbanandam R (2016). Healthcare waste management: An interpretive structural modeling approach. International Journal of Health Care Quality Assurance, 29(5): 559-581. Retrieved from https://doi.org/10.11o8/IJHCQA-02-2016-0010 